IKONOMIKA: Jurnal Ekonomi dan Bisnis Islam

Volume 5, No 2 (2020)

ISSN : 2527-3434 (PRINT) - ISSN: 2527-5I43 (ONLINE)

Page : I75 - I92

\title{
Rehabilitation and Reconstruction of the North-East: The Role of Sukuk Financing
}

\author{
Adam Muhammad Abubakar ${ }^{1}$, Nuraddeen Mohammed Lawa² \\ Department of Islamic Studies, Yobe State University,Damaturu ${ }^{1,2}$ \\ adamsguru@yahoo.com ${ }^{1}$,nuradddeenmlawal@yahoo.com²
}

\begin{abstract}
The Northeast region of Nigeria has been experiencing the devastating impact of Boko Haram insurgencysince 2009, which triggeredhumanitarian crisis and destruction of infrastructure,such as schools, hospitals, roads, bridges as well as homes and farmlands, leading to many becoming internally displaced persons and refugees. Both governmental and non-governmental organizations have been mostly providing relief services and materials, whilst only few Federal Government agencies and State Governmentsare providing reconstruction and rehabilitation due to insufficient sources of funds(Olaseni, 2012). The emergence of Sukuk to Nigerian Capital Market is a new development that provides alternative funding avenue for both State and Federal Governments to finance projects and infrastructure development for nation building (Alaro, 2020).It is against this backdrop that this study aims to reviewthe approaches of financing rehabilitation and reconstruction programmes in the Northeast and examines how the potentials ofSukuk financing could properly be utilized to complement the infrastructural deficit in the region. Thus, the research is an exploratory qualitative research that sourced cross sectional primary data collected through the use of structured questionnaire. Multistage purposive sampling method was employed in selecting the respondents for the study across the study area. Thematic Analysis was employed as the method of data analysis. Both descriptive and inferential statistics were used to summarize and interpret the results of the thematic analyses of the data obtained.
\end{abstract}

Keywords: North-East, Reconstruction, Rehabilitation and Sukuk Financing

\section{A. INTRODUCTION}

It has been established as a global norm and practicethat, following the devastating impact of disasters, there followa period of resettlement, reconstruction 
and rehabilitation.Since 2009, the Northeast region has been experiencing the devastating impact of Boko Haram insurgency which triggered humanitarian crisis and destruction of infrastructure,such as schools, hospitals, bridges as well as homes and farmlands, leading to many becoming internally displaced persons and refugees. The Federal Government and the Northeast State Governments, alongside the local and international Non-governmental organizations and development partners have been mostly providing relief services and materials, whilst only few Federal Government agencies and State Governmentsare providing reconstruction and rehabilitation. Generally speaking, funding has been a major challenge to infrastructural development in Nigeria for decades, since government resources can hardly meet the increasing demand. Consequently, government has relied on foreign loans to complement infrastructural deficit (Olaseni, 20I2). Though the emergence of Sukuk to Nigerian Capital Market is a new development, but it provides alternative funding avenue for both State and Federal Governments to finance projects and infrastructure development for nation building (Alaro, 2020). It is against this backdrop that this study aims to reviewthe approaches of financing rehabilitation and reconstruction programmes in the Northeast and examines how the potentials of Sukuk financing could properly be utilized to complement the infrastructural deficit in the region. As well, the study identifies the areas of priority that need to be rehabilitated and constructed via Sukuk financing as well as the appropriateSukuk model that will suit the peculiarities of rehabilitation and reconstruction programme.

According to Olaseni, (2012)funding has become a major challenge to infrastructural development in Nigeria for decades. As the country's population rises, demand for additional infrastructure in all sectors also increases. Unfortunately, the government resources can hardly meet the increasing demand. Consequently, government has relied on foreign loans to complement budgetary allocations in the provision of infrastructure.

As the Government of Nigeria makes progress in securing significant parts of the North-East, much of the region remains fragile.

Northeast region of Nigeria comprises 6 States: Adamawa, Bauchi, Borno, Gombe, Taraba and Yobe. According to the 2006 national census, the 6 States that comprise the Northeast region have a population of over I8.9 million, that is, I3.5\% of Nigeria's over I 40 million total population (NPC, 2006). As in many other regions of the savannah area, it is estimated that $70 \%$ percent of the population lives in rural areas where the primary occupation is agriculture. It is 
estimated that about80-90 percent of the population depends on agriculture, fisheries and livestock for their livelihoods and food security (FAO, 20I7).

The North-East Nigeria Recovery and Peace Building Assessment (RPBA) was conducted by the Government of Nigeria, with the support of the European Union (EU), the United Nations (UN) and the World Bank (WB) within the framework of the 2008 Joint EU-UN-WB Declaration on Post Crisis Assessments and Recovery Planning.The assessment report provides a shared understanding between the Government of Nigeria and its local and international partners on the peace building and recovery needs of the North-East. The report also sets a framework that could bridge the operational gap that can exist between humanitarian relief and recovery programmes, further encouraging a holistic approach to stabilization efforts in the North-East.

In essence, Ibrahim and Olu (20I5), recommended that the Governments should harmonize efforts with foreign partners and prioritize needs for an efficient allocation of scarce resources within the affected area. There is also the need for Federal and state Governments, in collaboration with the international community and partners to start the process of reconstructing the communities and rehabilitating the citizens who have been affected by the insurgency.

Subhani, (2010) observed that the global financial crisis of 2007 has created awareness of the ethical flaws of the conventional financial system. This in turn has the potential to make Islamic finance appeal beyond the Muslim World; because countries have deemed it necessary to search for a financial system that can withstand the taste of time and as a result the debate about the mission, operations and viability of the Islamic financial system has not only grown but has considerably widened.

The introduction of Islamic capital market has been a relatively recent development in Nigeria in comparison with the more established conventional products. The legal framework for the issuance of Sukuk in Nigeria was firstly enshrined in the Investments and Securities Act, 2007. Subsequently in February, 2013, SEC introduced new rules to regulate the issuance of Sukuk in Nigeria. According to Rule 572 of the SEC, "all public companies (including SPV's), state governments, local governments, and Government agencies as well as multilateral agencies are eligible to issue, offer or make an invitation of Sukuk upon seeking the Commission's approval” (SEC Rules 2013). 
This development led to the landmark issuance of first Sukuk in Nigeria, initiated in October, 2013 by the Osun State Government with the issuance of Sukuk worth NII.4 billion naira (approximately US\$73 million) to fund the development of 20 High Schools, 2 Middle Schools and 2 Elementary Schools in Osun State. It was issued at a rate of $14.75 \%$ per annum at N I,000 per unit and matures on 8th of October, 2020 (Oladele, 20I4). This millstone achievement is regarded as a turning point in the history of Sukukissuance in Nigeria, as such; Osun State Government is seen as trailblazer in this regard (Lotus Capital, 20I4).

However, at Federal Government level, the first Sukuk bond issuance was the Federal Government of Nigeria (FGN) NIO0.0 Billion IjarahSukuk, which was issued in 2017 with a tenor of seven (7) years and a Rental Income rate of 16.47\% per annum, which will be paid every six months. The proceeds were used to construct and rehabilitate 25 roads in Nigeria's 6 geopolitical zones selected by Ministry of Power, Works and Housing due to their strategic economic importance (DMO 2018).

Similarly, with the aim of promoting financial inclusion and deepening the investor base for FGN securities, the Debt Management Office (DMO) of Nigeria on Tuesday, July 23, 2019, listed on the Nigerian Stock Exchange, the second IOObn, 7-Year, FGN Sukuk due to mature in 2025. According to the CBN Half Year Activity Report, 2019: "The total FGN Sukuk Bonds outstanding at end-June 2019 stood at 200.00 billion, the two issues of the 7-year Sukuk of N100.00 billion each attracted rental rates of I6.47 and I5.74 per cent, respectively, payable semi-annually. The proceeds were targeted at the rehabilitation of roads across the six geopolitical zones (CBN Half Year Activity Report, 2019).

In a nutshell, the issuance of guidelines for the operations of Sukukin Nigeria by the Securities and Exchange Commission (SEC) creates economic value within a Shari'ahcompliant structure that has been successfully practiced in some jurisdictions, particularly, Asian countries and Middle-east in financing project and infrastructure development. Though the emergence of Sukuk to Nigerian Capital Market is a new development, but it provides alternative funding avenue for both State and Federal Governments to finance projects and infrastructure development for nation building.

Hence, Nigeria in general and Northeast in particular, will continue to reap from the benefits of Sukuk issuance taking into cognizance its potentialitiesin terms of economic growth,diversification, financial inclusion and infrastructural financing 
amongothers as wellas large Muslim population who would like to invest their money in an interest free Shari'ah compliant product.

\section{B. THEORITICAL}

Etymologically, Sukuk is an Arabic word that has its root in the word Sakk, which means financial instrument or cheque, it is reported that the modern cheque originated from this Arabic term. In modern financial terminology, Sukuk is commonly refers to as Islamic Bond, meaning a sharia-compliant financial certificate that represents proportionate beneficial ownership in the underlying tangible asset(s) of particular projects or investment activity (IIBI, 2019).

According to Accounting and Auditing Organization of Islamic Finance Institutions (AAOIFI) Sharia standard no.I7(2), the term Sukuk refers to a certificates of equal value representing undivided shares in ownership of tangible assets, usufruct and services or in ownership of the asset of particular project or special investment activity. Similarly, The Islamic Financial Service Board(IFSB) in its Capital Adequacy Standard(IFSB 2) defined Sukuk as "certificate that represents the holders proportionate ownership in an undivided part of underlying asset where the holder assumes all right and obligations to such asset”.

In Nigerian context, the Rules and Regulations of the Securities and Exchange Commission of Nigeria (SEC Rules 2013), defined Sukukas investment certificates or notes of equal value which evidences undivided interest/ownership of tangible assets, usufructs and services or investment in the assets of particular projects or special investment activity using Sharia principles and concepts as approved by the SEC.

According to Ayub, (2007), there are three (3) major parties involved in any Sukukstructure, namely: originator, investors and issuer. The originator is the government or corporate entity that intends to benefit from the Sukuk issuance, while the investors are certificate holders, the issuer called special purpose vehicle (SPV) is an independent legal entity that manages the pool of assets related to the Sukuk and acts as an intermediary between originator and investors.

According to the Accounting and Auditing Organization for Islamic Financial Institutions (AAOIFI) there are I4 different types of Sukuk allowed by Shariah. This include; Salam Sukuk (a kind of forward contract on sale of a particular commodity), IjaraSukuk (a lease contract), Istisna'aSukuk (use for project finance and in manufacturing), Hybrid Sukuk (comprising Istisna'a, Murabaha, and Ijarah pooled together), as well as Mudarabah (a profit sharing 
contract between parties to a transaction) and MusharakahSukuk (a partnership not much different from Mudharabah). It noteworthy that despite the variety of Sukuk, IjarahSukukremains the most popular type of Sukuk issued around the world by governments and corporate entities. This is due to its simplicity and favor with Sharia scholars, in addition to its similarity with "lease" financing in conventional financial system (Afshar, 20I3).

According to Olaniyi,Echchabi, and Alfarisi (2013): "Sometimes people perceive that Sukuk is similar to bonds, however, there are some elements that differentiate them, such as: nature, claims, security, principal and return, purpose, trading ofsecurity and responsibility of holders. The other distinctive feature of Sukuk is the approval of Shariah adviser to ensure that all aspects of Sukuk issuance comply with Shariah principles" PI40. This statement shows that Sukuk is very much analogous with conventional bond in terms of their purpose, objective and use, but Shariah distinguishes Sukuk in terms of mode of application and other features. Sukuk certificates are intended to replicate the functions of conventional bonds and tradable securities in resources mobilization from markets and injecting liquidity into the enterprise or government and in providing stable resource of income for investors. But, there are many differences that distinguish the Sukuk from debt bonds. But amongst them, the most important difference is that Sukuk structure must follow the basic requirements stipulated by Shariah principles regarding Islamic Financial transactions, for it to become a Shariah compliant product (Chik, 20I2). These basic requirements are the avoidance of Riba "interest", the avoidance of Gharar "uncertainty", the avoidance of any form of Maysir "gambling", and the avoidance of Islamically prohibited transactions such as alcohol, tobacco, pork-related products, conventional financial services, and immoral entertainment. On the other hand, debt bonds are based on loan contract to create indebtedness (Cakir and Raei, 2007).

However, in spite of the differences explained above, there are some similarities between Sukuk and debt bonds such as marketability, ratability, enhance-ability and versatility. Sukuk are marketable in the sense that they are monetized real assets that are liquid, easily transferred and traded in the financial markets. While ratability of Sukuk referred to its being easily rated, enhance-ability allows different Sukuk structures to be pooled for credit enhancements, and versatility which makes the variety of Sukuk structures for structuring across legal and fiscal domains, fixed and variable income options, (Alvi, 2006). 


\section{METHODOLOGY}

\section{Population and Sampling Technique}

The study adopted multistage sampling method in determining the appropriate respondents in the study. In the first stage, three (3) States (Adamawa, Borno and Yobe)were purposively selected out of the six States of the region. The choice of the States was informed by the fact that the selected States are the worst affected by the insurgency in the zone. In the second stage, three categories of stakeholders/entities(comprising Federal Government Agencies, State Governments and Non-Governmental Organizations) were purposively identifiedin each of the three selected States as the majorplayers/stakeholdersresponsible for the rehabilitation and reconstruction programmein the region, giving a total of nine (9) selected entities. In the third stage, threeAgencies/Ministries/organizations were purposively selected from each of the nine selected entities, giving a total number of twenty seven (27) organizations. In the fourth stage, threerespondents werepurposively selected from managerial cadre of each of the twenty seven organizations, giving a total number of eighty one (8I) respondents. The following table 4.I summarizes the entire population categories and sampling frame:

\section{Table I}

The Population and Sampling Frame.

\begin{tabular}{|c|c|c|c|c|c|}
\hline S/N & States & Entities & Organizations & Respondents & Total \\
\hline \multirow{9}{*}{ I. } & \multirow{9}{*}{ Adamawa } & Federal & FMF & 3 & \multirow{9}{*}{27} \\
\hline & & \multirow{2}{*}{ Agencies } & FMW & 3 & \\
\hline & & & NEDC & 3 & \\
\hline & & \multirow{3}{*}{$\begin{array}{l}\text { State } \\
\text { Government } \\
\text { Ministries }\end{array}$} & SMF & 3 & \\
\hline & & & SMW & 3 & \\
\hline & & & SMRR/SMHA & 3 & \\
\hline & & \multirow[t]{3}{*}{ NGOs } & UNICEF & 3 & \\
\hline & & & RESQUE & 3 & \\
\hline & & & COOPI & 3 & \\
\hline \multirow{6}{*}{2.} & \multirow{6}{*}{ Borno } & \multirow{3}{*}{$\begin{array}{l}\text { Federal } \\
\text { Agencies }\end{array}$} & FMF & 3 & \multirow{6}{*}{27} \\
\hline & & & FMW & 3 & \\
\hline & & & NEDC & 3 & \\
\hline & & \multirow{3}{*}{$\begin{array}{l}\text { State } \\
\text { Government } \\
\text { Ministries }\end{array}$} & SMF & 3 & \\
\hline & & & SMW & 3 & \\
\hline & & & SMRR/SMHA & 3 & \\
\hline
\end{tabular}




\begin{tabular}{|c|c|c|c|c|c|}
\hline & & \multirow[t]{3}{*}{$\mathrm{NGOs}$} & UNICEF & 3 & \\
\hline & & & RESQUE & 3 & \\
\hline & & & COOPI & 3 & \\
\hline \multirow{9}{*}{3.} & \multirow{9}{*}{ Yobe } & \multirow{3}{*}{$\begin{array}{l}\text { Federal } \\
\text { Agencies }\end{array}$} & FMF & 3 & \multirow{9}{*}{27} \\
\hline & & & FMW & 3 & \\
\hline & & & NEDC & 3 & \\
\hline & & \multirow{3}{*}{$\begin{array}{l}\text { State } \\
\text { Government } \\
\text { Ministries }\end{array}$} & SMF & 3 & \\
\hline & & & SMB & 3 & \\
\hline & & & SMHA\&DM & 3 & \\
\hline & & \multirow[t]{3}{*}{$\mathrm{NGOs}$} & UNICEF & 3 & \\
\hline & & & RESQUE & 3 & \\
\hline & & & COOPI & 3 & \\
\hline Total & 3 & 9 & 27 & $8 \mathrm{I}$ & $8 \mathrm{I}$ \\
\hline
\end{tabular}

\section{Source and Instrument for Data Collection:}

The study is an explorative qualitative research. Cross sectional data were collected from primary sourceandused for the main analysis in this study. Questionnaire method was used in collecting relevant information which are in form of opinions/views, from the sampled respondents selected from the population in the study area.In addition to that, documented secondary information was also utilized, which includes record from State Ministries of Finance; Ministry of Budget and Planning; Ministry of Works; Ministries of Humanitarian Affairs; Ministries of Rehabilitation, Resettlement and Reconstruction; Non-governmental development partners, journal papers and conference proceedings.

Both descriptive and inferential statistics were used to analyze the data for the study.

Thematic Analysis was employed as the methodof data analysis in this study. Thematic analysis is a method for identifying, analysing, and reporting patterns (themes) within data. It organises and describes your data set in detail and interprets various aspects of the research topic (Braun\&Clarke, 2006). However, they also argues that, thematic analysis should be considered a method in its own right as it provides a flexible and useful research tool, which can potentially provide a rich and detailed, yet complex account of data.

The qualitative data or the raw responses (opinions) from the primary respondents were logically arranged into discuss units according to each recommendation/selection of the respondents, then systematically converted into 
sub-themes, and further analyzed using the thematic method of data analysis, and scientifically extracted the themes (or the unanimous commonest/popular opinion of all the subjects), with a view to determine the findings. Descriptive statistics such as frequency distribution tables and percentages were utilized in summarizing, presenting and interpreting the results of the two conducted thematic analyses.

The study examined the correlation between the two variables ( $\mathrm{X} \& \mathrm{Y}$ ), where the Sukuk financing instrument is the independent variable (X), while the reconstruction and rehabilitation programmeis the dependent variable $(\mathrm{Y})$. The implicit correlation model is expressed thus:

$$
Y=f\left(\beta_{X_{j}}+u\right)
$$

Where:

$\mathrm{Y}=$ the reconstruction and rehabilitation programme

$\beta=$ a vector of coefficient to be estimated

$x_{j}=$ the Sukuk financing instrument

$u=$ error term

\section{RESULTS AND DISCUSSION}

Data Analysis and Interpretation

\section{Table 2}

Thematic Analysis I: The Appropriate Mode Of Financing The Rehabilitation And Reconstruction Programmein The Northeast

Question: What do you think is the most appropriate mode of financing rehabilitation and reconstruction programme in the North-East, and why?

\begin{tabular}{|c|l|l|l|}
\hline S/No & Themes & $\begin{array}{l}\text { Frequ } \\
\text { Ency }\end{array}$ & $\begin{array}{l}\text { Perce } \\
\text { Ntage }\end{array}$ \\
\hline I & $\begin{array}{l}\text { Statutory Allocations } \\
\begin{array}{l}\text { I. Statutory Allocation is the most reliable and } \\
\text { constant source of income with regular flow to } \\
\text { governments, that give room for proper state planning } \\
\text { and budget implementation and disbursement. } \\
\text { 2. It also provides ownership and sustainability of the }\end{array}\end{array}$ & II & I7\% \\
\hline
\end{tabular}


Rehabilitation and Reconstruction of the North-East:

The Role of Sukuk Financing

Adam Muhammad Abubakar ${ }^{1}$, Nuraddeen Mohammed Lawal ${ }^{2}$

\begin{tabular}{|c|c|c|c|}
\hline & $\begin{array}{l}\text { project, thereby preventing financial burden to the } \\
\text { benefitting community as well as avoiding the effect of } \\
\text { political/policy instability of governments. }\end{array}$ & & \\
\hline 2 & $\begin{array}{l}\text { Loans } \\
\text { I. Loans can be used to establish a business to get } \\
\text { profit. }\end{array}$ & 2 & $3 \%$ \\
\hline 3 & $\begin{array}{l}\text { Grants, Aids and Donations } \\
\text { I. Grants, Aids and Donations are very good source of } \\
\text { free funds used to supplement government's } \\
\text { Revenue. The government's statutory allocations and } \\
\text { IGR in most cases take care of only first line charges, } \\
\text { (salaries, pensions and gratuity), thus always not } \\
\text { enough to cater for huge capital intensive projects such } \\
\text { as the RR projects. } \\
\text { 2. GADs can also come either in cash or in kind, and } \\
\text { for different purposes (e.g. for health, education, } \\
\text { shelter, reconstruction, etc). } \\
\text { 3. Most of the current RR projects in the North-East } \\
\text { are financed through the GADs from both local and } \\
\text { international NGOs, donors, governments and private } \\
\text { sector. } \\
\text { 4. GADs, unlike in Loans and Sukuk, are free, hence } \\
\text { not a burdens or liabilities to be paid back by } \\
\text { governments. }\end{array}$ & I7 & $26.1 \%$ \\
\hline 4 & $\begin{array}{l}\text { Sukuk } \\
\text { I. Sukuk is an interest-free, ethical and shariah } \\
\text { compliant source of funding long term capital } \\
\text { intensive projects. } \\
\text { 2. Sukuk is better than Loan in the sense that Sukuk is } \\
\text { an asset backed financial instrument in which the } \\
\text { Sukuk holders or the investors have direct ownership } \\
\text { in the underlying asset/project. } \\
\text { 3. Sukuk is suitable for infrastructure financing e.g. it } \\
\text { has already been successfully issued in Nigeria for the } \\
\text { ongoing road construction and other infrastructures. } \\
\text { 4. Sukuk projects help in curbing }\end{array}$ & 24 & $37 \%$ \\
\hline
\end{tabular}




\begin{tabular}{|c|c|c|c|}
\hline & $\begin{array}{l}\text { corruption/nepotism, increasing efficiency and cost } \\
\text { effectiveness, because the Sukuk project is usually } \\
\text { executed or supervised by the third party (SPV) } \\
\text { before handing over to the government. } \\
5 \text {. It also serves as an avenue for alternative source of } \\
\text { government funds/revenue in addition to its statutory } \\
\text { allocations and loans } \\
\text { 6. It could be used for public private partnership, for } \\
\text { financial diversification and for rapid economic } \\
\text { development. }\end{array}$ & & \\
\hline 5 & $\begin{array}{l}\text { Others } \\
\text { No valid theme. }\end{array}$ & I & $1.5 \%$ \\
\hline 6 & No Response & $\mathrm{IO}$ & I5.4\% \\
\hline Total & & 65 & $100 \%$ \\
\hline
\end{tabular}

The above table 5.I shows the summary of the resultfrom our thematic analysis I (see the attached appendix), where we have five recommendations (Statutory Allocations, Loans, Grants Aids \& Donations, Sukuk and Others) and their respective themes (numbered I-n beneath) that emerged from the analysis of the collected qualitative data (opinions) of the 65 respondents on the above question.

The result shows that, II respondents (I7\%) recommended the use of statutory allocation in financing the $\mathrm{RR}$ in the $\mathrm{NE}$ due to the above two major themes extracted from their reasons. 2 respondents (3\%) opted for the collected of loans for the RR in the NE with one theme above. 17 respondents $(26.1 \%)$ are on the opinion that Grants, Aid, and Donations are the most appropriate means of financing the $\mathrm{RR}$ in the $\mathrm{NE}$, the above four major themes were extracted from their collective opinions. 24 (37\%) out of the 65 total respondents opined that Sukuk will be the most suitable source of funding the RR in the NE because of the above 6 different themes collated from their various supplied reasons. I respondent (I.5\%)opted for other means of funding other than the above four, with no valid reason. While the remaining 10 respondents representing (I5.4\%) of the contacted respondents could not respond to this question due to reasons known to them.

The result of the above thematic analysis and their respective frequencies suggests that the issuance of Sukuk will be the best means of financing the rehabilitation and reconstruction $\operatorname{program}(\mathrm{s})$ in the Northeast amongst all other 
Rehabilitation and Reconstruction of the North-East:

The Role of Sukuk Financing

Adam Muhammad Abubakar ${ }^{1}$, Nuraddeen Mohammed Lawal ${ }^{2}$

listed sources of project funding such as the statutory allocations, loans, grant, aids and donations. This was justified by the fact that the choice of Sukuk by the respondents has the highest frequency of 24 who constitute the highest percentage of $37 \%$, with the highest number of six extracted themes, which are the modest unique potential advantages which the Sukuk financing has over other means.

\section{Table 3}

\section{Thematic Analysis 2: The Most Critical Areas For Rehabilitation And Reconstruction In The Northeast}

Question: Which of the following areas do you think is the most critical for rehabilitation and reconstruction in the North-East, and why?

\begin{tabular}{|c|c|c|c|}
\hline S/NO & Themes & $\begin{array}{l}\text { Frequ } \\
\text { Ency }\end{array}$ & $\begin{array}{l}\text { Perce } \\
\text { Ntage }\end{array}$ \\
\hline I & $\begin{array}{l}\text { Housing } \\
\text { I. Because } 80 \% \text { of the houses destroyed belong to the } \\
\text { low income earners. } \\
\text { 2. Shelter is the next most important basic need after } \\
\text { food and clothing, lest schools and hospitals. } \\
\text { 3. Houses are the most destroyed in the insurgency. } \\
\text { 4. In order to enable the victims in the IDP camps to } \\
\text { have settlement before any other thing follow. }\end{array}$ & $\mathrm{I} 3$ & $20 \%$ \\
\hline 2 & $\begin{array}{l}\text { Schools } \\
\text { I. Investment in education is the foundation of every } \\
\text { successful society, and can lead to revitalization of } \\
\text { other sectors. } \\
\text { 2. Education is the most utilized and development } \\
\text { need of the populace. } \\
\text { 3. Most schools have suffered massive destruction; in } \\
\text { fact, it is the most affected sector. } \\
\text { 4. High rate of drop out in both western and Islamic } \\
\text { studies in the North-East remain source of high } \\
\text { poverty in the region. } \\
\text { 5. The genesis of this insurgency is the lack of } \\
\text { education and poverty. } \\
\text { 6. Reviving the education system and enlightening the }\end{array}$ & 19 & $29.2 \%$ \\
\hline
\end{tabular}




\begin{tabular}{|c|c|c|c|}
\hline & $\begin{array}{l}\text { younger generation is the key to stop the continuation } \\
\text { of the insurgency. } \\
\text { 7. Most of the schools are over-populated, which } \\
\text { leads to poor learning condition in lower learning } \\
\text { level. }\end{array}$ & & \\
\hline 3 & $\begin{array}{l}\text { Hospitals } \\
\text { I. High level of poverty degenerates to all sort of } \\
\text { diseases, demanding urgent attention. } \\
\text { 2. With improved health status of the people the } \\
\text { injury standard will improve. } \\
\text { 3. People may not have good roads but they must } \\
\text { need health care to survive in any critical conditions } \\
\text { and to pursue sustenance. } \\
\text { 4. With good hospitals, the money we spend for } \\
\text { medical trips abroad will reduce. And it may be a } \\
\text { source of tourism and foreign exchange earnings from } \\
\text { neighboring countries. } \\
\text { 5. Health is critical even for the most developed } \\
\text { countries, especially during this Covid-I9 pandemic. }\end{array}$ & 7 & $10.8 \%$ \\
\hline 4 & $\begin{array}{l}\text { Roads and Bridges } \\
\text { I. It is a capital intensive long term project. } \\
\text { 2. They are highly dilapidated, thus they pose } \\
\text { insecurity and facilitate the insurgency in the NE. } \\
\text { 3. Road transportation and accessibility to remote } \\
\text { communities are very difficult because most of the } \\
\text { roads and bridges in the NE were constructed since } \\
\text { I999, and they are now mostly damaged. }\end{array}$ & $\mathrm{IO}$ & $\mathrm{I} 5.4 \%$ \\
\hline 5 & $\begin{array}{l}\text { Others (e.g. Government Offices, Market, Shops) } \\
\text { Returnees would also need to conduct their } \\
\text { businesses/trading activities because of the poor } \\
\text { standard of living in majority of the people. }\end{array}$ & 5 & $7.8 \%$ \\
\hline 6 & No Response & II & $16.9 \%$ \\
\hline Total & & 65 & $100 \%$ \\
\hline
\end{tabular}

The above table 5.2 shows the summary of the result from our thematic analysis 2 (see the attached appendix), where we have five recommendations 
(Housing, Schools, Hospitals, Roads \& Bridges and Others) and their respective themes (numbered I-n beneath) that emerged from the analysis of the collected qualitative data (opinions) of the 65 respondents on the above question.

The result shows that, I3 respondents (20\%) recommended the Housing as the first critical infrastructure to be rehabilitated and reconstructed in the northeast due to the above four major themes which were extracted from their reasons. 19 respondents $(29.2 \%)$ opted for schools as the most critical area to be reconstructed and rehabilitated in the NE due to theseven themes mentioned above. 7 respondents $(\mathrm{I} 0.8 \%)$ are on the opinion that hospitals require theurgent reconstruction and reconstruction in the northeast, the above five major themes were extracted from their divergent views. IO (I5.4\%) out of the 65 total respondents opined that roads and bridges are more dilapidated, and thus needed the immediate revival in the NE because of the above three different themes deduced from their variety of perceptions. 5 respondents (7.8\%) argued for infrastructures other than the above four (e.g. Government Offices, Markets or Shops), with the above valid reason. While the remaining II respondents representing (16.9\%) of the total contacted respondents did not respond to this question due to some reasons.

The findings of the above thematic analysis 2, the themes and their respective frequencies suggest that the schools as well as the entire education sector is the most critical area that requires immediate attention in the rehabilitation and reconstruction programme(s) in the Northeast amongst all other listed potential areas to revive. This was justified by the fact that the choice of schools by the respondents has the modest frequency of 19 which constitutes the highest percentage of $29.2 \%$, and has the highest number of seven extracted themes, which justify the significance of starting with schools over other destroyed infrastructures.

\section{Table 4}

\section{Thematic Analysis 3: The Most Suitable Sukuk Models For Rehabilitation And Reconstruction In The North-East}

Question: Which of the following Sukuk models do you think will suit the peculiarities of rehabilitation and reconstruction programme of the North-East?

\begin{tabular}{|c|l|l|l|}
\hline S/No & \multicolumn{1}{|c|}{ Sukuk Models } & $\begin{array}{c}\text { Frequ } \\
\text { Ency }\end{array}$ & \multicolumn{1}{c|}{$\begin{array}{c}\text { Perce } \\
\text { Ntage }\end{array}$} \\
\hline I & IjarahSukuk Model & 9 & I3.8\% \\
\hline 2 & IstithnaSukuk Model & I5 & $23 \%$ \\
\hline
\end{tabular}




\begin{tabular}{|c|l|l|l|}
\hline 3 & MudharabahSukuk Model & 5 & $7.7 \%$ \\
\hline 4 & MusharakahSukuk Model & 7 & $10.8 \%$ \\
\hline 5 & Others & 5 & $7.7 \%$ \\
\hline 6 & No Response & 24 & $37 \%$ \\
\hline Total & & 65 & $100 \%$ \\
\hline
\end{tabular}

Table 5.3 above shows the frequency distribution of the respondents who recommended the suitable Sukuk model to be adopted amongst the above four listed feasible models, if Sukuk is to be issued in order to raise sufficient funds for the rehabilitation and reconstruction programme in the northeast.

The frequency table shows that, 9 respondents (I3.8\%) recommended the use of IjarahSukuk Model, I5 respondents (23\%) suggested the adoption of IstithnaSukuk Model, 5 respondents (7.7\%) opted for MudharabahSukuk Model, while 7 respondents (10.8\%) chose the utilization of MusharakahSukuk Model. 5 respondents $(7.7 \%)$ suggested for other types of Sukuk which are not among the above four listed major Sukuk models. While significant number of the respondents could not answer this question, perhaps due to its technicality as some of the respondents are not experts or are not well knowledgeable in mastering the new Sukuk instrument.

The result shows that the respondents unanimously agreed that the IstithnaSukuk Model is the best model,among other Sukuk models, to be used in the rehabilitation and reconstruction programme in the northeast. The selection of the Istithna Model is justified by the fact that most of the reconstruction and rehabilitation projects are on the existing infrastructures or government owned assets, not on a new project. And even theoretically, Istithna is the most appropriate Sukuk Model that can suit a project/asset of this nature.

\section{E. CONCLUSION}

The study has revealed the potential roles, as well as the comparative advantages, of Sukuk financing over and amongst other sources of funds, on the reconstruction and rehabilitation programme of the destroyed infrastructures in the northeast region of Nigeria due to the effects of the current insurgency of Boko Haram. The study also found out the critical areas of priority that urgently need to be rehabilitated and constructed via Sukuk financing. According to the findings, schools are the most critical infrastructure that should be reconstructed and 
rehabilitated before other projects. Finally, the study also identified Istithna Sukuk Model as the most appropriate Sukuk model that should be applied if Sukukinstrument is to be issued for the financing of rehabilitation and reconstruction programme in the region.

Therefore, the study recommends the consideration of issuing Istithna Sukuk to raise funds for the reconstruction and rehabilitation of Schools and other infrastructures in the Northeastern States of Nigeria.

\section{Acknowledgement}

The researchers acknowledged TET Fund for providing funds to carry out this research.

\section{REFERENCES}

Abdul-Aziz et al (20I4) "Risk in funding infrastructural project through Sukuk or Islamic bonds" Vol. 3 issue .2

Accounting and Auditing Organization for Islamic Financial Institutions (AAOIFI) Rule I7(2)

Adorn, N. Thomas, A. (2004). Islamic Bonds: Your Guide to Issuing, Structuring and Investing in Sukuk. London: Euro moneyBooks

Afshar,T. (2013). Compare and Contrast Sukuk (Islamic Bonds) withConventional Bonds, Are they Compatible? Journal of Global Business Management 9(I)

Alvi, I. (2006), 'Review on Several Sukuk Products Issued Worldwide', KLIFF Malaysia

Anuar, M. M., \& Adam, F. (20I2). Muslim Consumers ' Perception on Internet Banking Services, 3(5), 63-72.

Ayub M. (2007) “ Understanding Islamic Finance” publish by John Wiley \& son Ltd

Braun V., \&Clarke V., (2006).Using thematic analysis in psychology. Thematic analysis revised.http://eprints.uwe.ac.uk/II735/I/thematic_analysis_revised__final.doc

Cakir, S. and Raei, F. (2007), 'Sukuk vs. Eurobonds: Is there a difference in Valueat-Risk?’, IMF working paper, WP/07/237Chapra, M. U and Ahmed H. (2002) "corporate governance for Islamic financial institutions" Occasional 
paper no. 6, Islamic research and training institute, Islamic development bank Jeddah, Saudi Arabia

CBN Half Year Activity Report, 2019

Chaudhry, M. S. (1999), Fundamentals of Islamic Economic System. First Edition, Burhan Education and Welfare Trust. Lahore, Pakistan.

Chik M. N., (2012). Sukuk. Shari'ah guidelines for Islamic bonds. Islamic Banking Operation and Regulatory Framework Workshop, Centre for Banking Studies, Central Bank of Sti Lanka.

Debt Management Office [DMO]. (2017). FGN DebutSukuk Offer Oversubscribed. Press Release, September,26. Retrieved from: http://www.dmo.gov.ng/fgnbonds/sovereign-Sukuk

DMO (20I I) Annual report p. I2-I4, Nigeria.

Hanefah, M. M., \&Sains, U. (2013).Sukuk: global issues and challenges. Journal of Legal,Ethical and Regulatory Issues, I6 I), I07-I20.

IIBI, (2019). Glossary of Financial Terms. United Kingdom https://www.islamicbanking.com/explore/glossary/glossary-financial-terms-s retrieved 30th August, 2019

ISRA (2014) "Islamic financial system principles and operations" Lorong university A Kuala lumpur Malaysia pp. 389-443

Lotus Capital, (2014).DMO to encourage Sukuk bond in Nigeria, https://www.lotuscapitallimited.com/index.php/78-news/I34-dmo-toencourage-Sukuk-bond-in-nigeria 30-Dec-I9

Obaidullah, M(2005) "Islamic financial markets" Islamic economics research Centre, king Abdul-Aziz University Jeddah Saudi Arabia

Oladele, M.O (20I4). Sukuk as a tool for infrastructural development in Nigeria, https://www.researchgate.net/publication/299398297_SUKUK_AS_AN _ALTERNATIVE_SOURCE_OF_FUNDS_FOR_NIGERIAN_GOVE RNMENT [accessed May 30 2020].

Oladunjoye, M. O. (20I4). Sukuk as a Tool for Infrastructural Development in Nigeria.Journal of Islamic Banking and Finance, 2(I), 335-344.

Olaniyi, O. N., Echchabi, A. G. and Alfarisi, M. F. (2013), Sukuk as An Alternative Mechanism for Infrastructure Development and Improvement of Small Businesses in Nigeria, a paper published in 'Essentials of Islamic Banking and Finance in Nigeria' edited by Dandago, K. I., Muhammad, A. D., and Oseni, A. U., by Benchmark Publishers Limited, Kano, Nigeria. 
Rehabilitation and Reconstruction of the North-East:

The Role of Sukuk Financing

Adam Muhammad Abubakar ${ }^{1}$, Nuraddeen Mohammed Lawal ${ }^{2}$

OlaseniM.Alade (2012) "Vision 20:2020 and the challenges of infrastructural development in

Salisu, Y. (2015).Sukuk as an Alternative Source of Funding Infrastructural Development in Nigeria, $2^{\text {nd }}$ IIIBF conference, BUK, Kano

Securities and Exchange Commission, Nigeria, Corporate Bonds Issued in Nigeria (I960 to 2013). [Online] Available: http://www.sec.gov.ng/corporatebonds-issued-\%281960- to-2013\%29.html (December 16, 20I3).

Securities Commission Malaysia.(2004). Guidelines on the Offering of Islamic Securities.Kuala Lumpur: Securities Commission.

Usmani, M. T (2008) Sukuk and their contemporaty applications.www.failaka.com/downloads/usmanSukukapplications.pdf.

Wilson, R (2007) "the development of Islamic finance in the GCC ".Kuwait the Centre for the study of global governance.

Wilson, R. (2004), "Overview of the Sukuk market" in Adam, N.J. and A. Thomas (eds.), Islamic Bonds: Your Guide to Issuing, Structuring and Investing in Sukuk, Euromoney Books, London 
IKONOMIKA

Volume 5, No 2 (2020)

https://ejournal.radenintan.ac.id/index.php/ikonomika

E-mail: ikonomika_submission@radenintan.ac.id 